\title{
Çoxprofilli klinikalarda cərrahi yara infeksiyalarının etiologiyası
}

\author{
S.A.Atakişizadə ${ }^{1}$ \\ ${ }^{1}$ Azarbaycan Tibb Universitetinin yoluxucu xastaliklar kafedrası
}

Cərrahi müdaxilə nahiyyəsi infeksiyaları (CMNI) xəstəxanadaxili infeksiyalar arasında 30\%-dən çox rast gılinməklə sidik yolları infeksiyaları və pnevmoniyalardan sonra üçüncü yerdə durur. Effektli müalicə və profilaktika məqsədilə hər bir cərrahi klinikada rast gəlinən CMNİ törədiciləri və onların antibiotiklərə qarşı həssaslığı qabaqcadan nəzərə alınmalıdır. Tədqiqatın məqsədi 2014-2016-cı illərdə ATU Tədris Cərrahiyyə klinikasında rast gəlinən CMNİ etioloji agentlərinin və onların antimikrob preparatlara həssaslıq və rezistentliyinin araşdırılması olmuşdur. Araşdırma nəticəsində CMNİ əsas törədicilərinin S.aureus, P.aeruginosa, E.coli, Klebsiella cinsli bakteriyalar, eləcə də Candida cinsli göbələklər olması müəyyən edilmişdir. P.aeruginosa, E.coli və Klebsiella cinsli bakteriyalar əksər antibiotiklərə davamlı olması ilə fərqlənmişlər. E.coli və Klebsiella cinsli bakteriya ştammlarının əksəriyyətində genişlənmiş spektrli beta-laktamaza (ESBL), P.aeruginosa ştammlarının isə təqribən yarısında induksiya olunan betalaktamaza (İsBL) produksiyası müəyyən edilmişdir.

Açar sözlor: carrahi müdaxila nahiyyasi infeksiyalarl, mikroorqanizmlar, antibiotiklara hassaslıq

Corrahi omoliyyatlardan sonrak1 infeksiyalar - corrahi yara infeksiyaları cərrahiyyədə xəstələnmə və ölümün əsas səbəblərindəndir. Cərrahi stasionarlarda rast gəlinən xəstəxanadaxili-nazokomial infeksiyalar (XDI) əsasən cərrahi əməliyyatlarla əlaqədar olduğundan son zamanlar cərrahi yara infeksiyaları (CYI) termini işlədilir. Lakin cərrahi stasionarlardakı XDİ təkcə cərrahi yaralarla əlaqədar olmur. Məsələn, cərrahi əməliyyatlardan sonra reanimasiya şöbələrində baş verə bilən ağciyərlərin süni ventilyasiyası ilə əlaqədar, eləcə də bu xəstələrdə damardaxili kateterlərlərin uzunmüddətli istifadəsi ilə əlaqədar xəstəxanadaxili infeksiyaları cərrahi yara infeksiyaları adlandırmaq heç də düzgün deyil. Beləliklə, CYİ termini əvəzinə cərrahi müdaxilə nahiyyəsinin infeksiyası (CMNİ) termininin işlədilməsi daha məqsədəuyğundur. CMNİ invaziv (cərrahi) əməliyyatlarından sonra baş verən infeksiyalarıdır. XDİ arasında rastgəlinmə tezliyinə görə CMNI sidik yolları infeksiyaları və pnevmoniyalardan sonra üçüncü yerdə durur. Nozokomial infeksiyaların 30\%-dən çoxu CMNI payına düşür [3]. Ona görə də cərrahi əməliyyatlardan bilavasitə əvvəl və q1sa müddət sonra antibiotiklərin profilaktik istifadəsi yaraların əməliyyat zamanı kontaminasiyasına və cərrahi yara infeksiyalarının inkişafına qarşı yönəldilməlidir. Bunun üçün hər bir cərrahi klinikada rast gəlinən CMNİ törədiciləri və onların antibiotiklərə qarşı həssaslığı qabaqcadan nəzərə alınmalidir.

Tədqiqatın məqsədi 2014-2016-c1 illərdə ATU Tədris Corrahiyyə klinikasında rast gəlinən CMNİ etioloji agentlorinin və onların antimikrob preparatlara həssaslıq və rezistentliyinin araşdırılması olmuşdur.

Material və metodlar. Corrahi əməliyyatlardan sonra baş verən CMNİ zamanı yara, drenaj və abses möhtəviyyatlarının mikrobioloji müayinəsi aparılmışdır. Müayinə üçün materiallar steril pambıq tamponlardan, yaxud birdəfəlik şprislərdən istifadə edilməklə götürülmüşdür. Drenaj möhtəviyyatı drenaj borusunu antiseptik məhlullarla islədikdən sonra, abses möhtəviyyatı isə steril şpris vasitəsilə punksiya vasitəsilə əldə edilmişdir. Nümunələr müxtəlif qidalı mühitlərə - Müller Hinton aqarı, qanlı aqar, EMB, Saburo mühitlərinə inokulyasiyadan sonra bir - iki gün inkubasiya edilmiş, alınmış kulturalar ümumi qəbul edilmiş üsullarla (morfoloji, kultural, biokimyəvi və $\mathrm{s}$. əlamətləri nəzərə almaqla) identifikasiya edilmişdir. Mikroorqanimlərin antibiotiklərə həssaslığı disk-diffuziya üsulu ilə EUCAST 
(antimikrob preparatlara həssasliq testi üzrə Avropa komitəsinin) təklifləri (European Committee on Antimicrobial Susceptibility Testing. Breakpoint tables for interpretation of MICs and zone diameters. Version 4.0, valid from 2014-01-01) nəzərə alınmaqla aparılmışdır.

Nəticələr. 40 xəstədən əldə edilmiş cəmi 40 materialın müayinəsi nəticəsində 56 mikroorqanizm ştammı əldə edilmişdir ki, bunlar da cins və növ mənsubiyyətinə görə geniş spektrə malik olmuşdur. Oldə edilmiş mikroorqanizmlər və onların rasgəlmə tezliyi 1-ci cədvəldə göstərilmişdir.

\section{Codvəl 1}

Cərrahi müdaxilə nahiyyəsi infeksiyalarının etiologiyası

\begin{tabular}{|c|l|l|l|}
\hline $\mathrm{N}$ & Mikrorqanizm & Sayı & $\%$ \\
\hline 1. & Staphylococcus aureus & 14 & 25,0 \\
\hline 2. & $\begin{array}{l}\text { Pseudomonas } \\
\text { aeruginosa }\end{array}$ & 9 & 16,1 \\
\hline 3. & Escherichia coli & 13 & 23,2 \\
\hline 4. & Klebsiella spp. & 7 & 12,5 \\
\hline 5. & Enterobacter spp. & 2 & 3,6 \\
\hline 6. & Acinetobacter spp. & 2 & 3,6 \\
\hline 7. & Enterococcus spp. & 2 & 3,6 \\
\hline 8. & Proteus spp. & 1 & 1,8 \\
\hline 9. & Candida spp. & 6 & 10,7 \\
\hline 10. & Cəmi & 56 & 100 \\
\hline
\end{tabular}

Müayinə materiallarının bir qismində mikoorqanizmlərin assosiasiyası müşahidə edilmişdir. Codvəldən göründüyü kimi Staphylococcus aureus, Escherichia coli, Pseudomonas aeruginosa vo Klebsiella cinsli bakteriyalar daha çox rast gəlinərək dominant törədicilər olmuşdur. Candida cinsli göbələklər də əhəmiyyətli sayda rast gəlinmişdir. Oldə edilmiş 6 Candida cinsindən əksəriyyəti C.albicans növünə, biri C.tropicalis, biri isə C.lusitaniae növünə aid olmuşdur.
Dominant törədici mikrorqanizmlərin antbiotiklərə həssaslığını öyrənərkən Candida cinsli göbələklərdə antifunqal prerparatların (amfoterisin B, flukonazol, vorikanozol, ketokonazol, nistatin) heç birisinə rezistentlik müəyyən edilməmişdir. Belə ki, Candida cinsli göbələklərin bütün ştammaları göstərilən antifunqal preparatlara qarşı həssas olmuşlar.

S.aureus ştammları əsasən oksasillin, sefoksitin, eritromisin, vankomisin, klindamisin, amikasin, gentamisin, tigesiklin, levofloksasin, xloramfenikol, sulfometaksozol-trimetoprim, rifampisin və linezolidə həssas olmuşlar (cədvəl 2). $\mathrm{Bu}$ bakteriya ştammlarının əksəriyyəti penisillinə, ampisillinə, böyük bir qismi (14 ştammdan 6-si) isə tetrasiklinə davamlı olmuşdur. Klindamisinə induksiya olunmuş resistentlik (indusable klindamisine resistance) 14 ştammdan ancaq ikisində (14,3\%) müşahidə edilmişdir. Ştammların ikisi (14,3\%) MRSA kimi differensiasiya edilmişdir.

Oldə edilmiş P.aeruginosa ştammlarında bir çox antibiotiklərə davamlılıq müşahidə edilmişdir. Belə ki, bu bakteriya ştammlarının əksəriyyəti seftazidimə, sefepimə, piperasillinə, meropeneme, aztreonama davamlı olmuşdur. P.aeruginosa ştammlarının hamısı imipenemə, böyük bir qismi siprofloksasinə, levofloksasinə, gentamisinə, amikasinə və kolistinə həssas olmuşdur. Ştammların 4-də $(44,4 \%)$ induksiya olunan betalaktamaza (İsBL) fermenti pozitiv olmuşdur.

Klebsiella cinsli bakteriya ştammlarının hamıs1 ampisillinə, ampisillin+sulbaktama, amoksisillin+clavunata, sefalosporinlərə, o cümlədən III nəsil sefalosporinlərinə, siprofloksasinə, aztreonama, gentamisinə, trimetoprim- sulfametoksazola, böyük əksəriyyəti isə piperasillin+tazobaktama, ofloksasinə, levofloksasinə, moksifloksasinə, xloramfenikola davamlı olmuşlar. Ştammların hamısı imipenemə, böyük əksəriyyəti isə doripeneme, tigesiklinə və koistinə həssas olmuşdur. Bunların əksəriyyətində 
(7 ştammdan 6-da - 85,7\%) ESBL (Extended-

CMNI dominant törədicilərinin antibiotiklərə Spectrum Beta-Lactamases - genişlənmiş spektrli həssaslığ 1

beta-laktamaza) sintezi müəyyən olunmuşdur.

Codvəl 2.

\begin{tabular}{|c|c|c|c|c|c|c|c|c|}
\hline \multirow{2}{*}{ Antibiotik } & \multicolumn{2}{|c|}{$\begin{array}{c}\text { Staphylo-coccus } \\
\text { aureus }\end{array}$} & \multicolumn{2}{|c|}{$\begin{array}{c}\text { Pseudomonas } \\
\text { aeruginosa }\end{array}$} & \multicolumn{2}{|c|}{$\begin{array}{l}\text { Klebsiella } \\
\text { spp. }\end{array}$} & \multicolumn{2}{|c|}{$\begin{array}{l}\text { Escherichia } \\
\text { coli }\end{array}$} \\
\hline & $\mathrm{H}$ & $\mathrm{D}$ & $\mathrm{H}$ & $\mathrm{D}$ & $\mathrm{H}$ & $\mathrm{D}$ & $\mathrm{H}$ & $\mathrm{D}$ \\
\hline Penisillin & 0 & 14 & - & - & - & - & - & - \\
\hline Ampisilin & 1 & 13 & - & - & 0 & 7 & 1 & 12 \\
\hline Oksasilin & 12 & 2 & - & - & - & - & - & - \\
\hline Ampisilin+ Sulbak. & - & - & - & - & 0 & 7 & 5 & 8 \\
\hline Amoksisillin+Clav. & - & - & - & - & 0 & 7 & 7 & 6 \\
\hline Sefuroksim & - & - & - & - & 0 & 7 & 1 & 12 \\
\hline Seftriakson & - & - & - & - & 0 & 7 & 1 & 12 \\
\hline Sefotaksim & - & - & - & - & 0 & 7 & 1 & 12 \\
\hline Seftazidim & - & - & 2 & 7 & - & - & - & - \\
\hline Sefepim & - & - & 1 & 8 & 1 & 6 & 2 & 11 \\
\hline Sefoksitin & 13 & 1 & - & - & 6 & 1 & 11 & 2 \\
\hline Eritromisin & 11 & 3 & - & - & - & - & - & - \\
\hline Vankomisin & 13 & 1 & - & - & - & - & - & - \\
\hline Klindamisin & 11 & 3 & - & - & - & - & - & - \\
\hline İmipenem & - & - & 9 & 0 & 7 & 0 & 13 & 0 \\
\hline Meropenem & - & - & 3 & 6 & 4 & 3 & 10 & 3 \\
\hline Ertapenem & - & - & - & - & 4 & 3 & 11 & 2 \\
\hline Doripenem & - & - & - & - & 6 & 1 & 11 & 2 \\
\hline Piperasillin & - & - & 1 & 8 & - & - & - & - \\
\hline Piperasillin+Tazob. & - & - & 4 & 5 & 2 & 5 & 7 & 6 \\
\hline Aztreonam & - & - & 0 & 9 & 0 & 7 & 1 & 12 \\
\hline Gentamicin & 13 & 1 & 6 & 3 & 0 & 7 & 8 & 5 \\
\hline Amikacin & 13 & 1 & 6 & 3 & 3 & 4 & 12 & 1 \\
\hline Netilmicin & & & 5 & 4 & 3 & 4 & 10 & 3 \\
\hline Tigecycline & 13 & 1 & - & - & 5 & 2 & 11 & 2 \\
\hline Ofloksasin & - & - & - & - & 1 & 6 & 6 & 7 \\
\hline Ciprofloksasin & - & - & 6 & 3 & 0 & 7 & 7 & 6 \\
\hline Levofloksasin & 13 & 1 & 6 & 3 & 1 & 6 & 6 & 7 \\
\hline Moksifloksasin & - & - & - & - & 1 & 6 & 7 & 6 \\
\hline Xloramfenikol & 12 & 2 & - & - & 1 & 6 & 7 & 6 \\
\hline Tetrasiklin & 8 & 6 & - & - & - & - & - & - \\
\hline $\begin{array}{l}\text { Trimetoprim- } \\
\text { Sulfametoksazol }\end{array}$ & - & - & - & - & 0 & 7 & 2 & 11 \\
\hline Kolistin & - & - & 8 & 1 & 5 & 2 & 12 & 1 \\
\hline Rifampisin & 13 & 1 & - & - & - & - & - & - \\
\hline Linezolid & 13 & 1 & - & - & - & - & - & - \\
\hline
\end{tabular}

Qeyd: H - həssas ştammların sayı; D - davamlı ştammların sayı; “_“" - həssaslıq təyin edilməmişdir. 
Cərrahi müdaxilə nahiyyəsi infeksiyalarının dominant etioloji amillərindən olan E.coli ştammlarının böyük əksəriyyəti ampisillinə, sefalosporinlərə, o cümlədən III nəsil sefalosporinlərinə, aztreonama, trimetoprimsulfametoksazola davamlı olmuşlar. Ştammların hamısı imipenemə, böyük əksəriyyəti isə digər karbopenemlərə, sefoksitinə, amikasinə, netilmisinə, tigesiklinə və koistinə həssas olmuşdur. Bunların əksəriyyətində (13 ştammdan 12-də - 92,3\%) ESBL sintezi müəyyən olunmuşdur.

Müzakirə. Әdəbiyyat məlumatlarına əsasən CMNİ törədicilərinin spektri çox genişdir. Müxtəlif tədqiqatlarda dominant törədicilərin əsasən stafilokoklar, enterokoklar, E.coli və P.aeruginosa olduğu qeyd edilir. Məsələn, bir tədqiqatda cərrahi əməliyyatlardan sonrakı XDİ etioloji strukturunda Escherichia coli - 31,25\%, P.aeruginosa - $25 \%$ və S.aureus - 22\% aşkar edilmişdir [4]. Son zamanlar cərrahi yara infeksiyalarının etiologiyasında S.aureus-un rolunun artması qeyd edilir [2]. Qeyd etmək lazımdır ki, bizim tədqiqatda CMNI törədicilərinin rastgəlinmə tezliyi yuxarıda göstərilən tədqiqatların nəticələri ilə müəyyən qədər uyğunlaşır. Belə ki, qeyd edildiyi kimi, bizim tədqiqatda S.aureus (25\%), E.coli (23,3\%), P.aeruginosa $(16,1 \%)$ və Klebsiella cinsli bakteriyalar $(12,5 \%)$ daha çox rast gəlinərək dominant törədicilər olmuşdur.

Təsadüfi deyil ki, CMNI törədiciləri antibiotiklərə davamlılığı ilə fərqlənir. Toniolo A. və b. [7] 2001-2002-ci illərdə cərrahi pasientlərdən əldə edilmiş mikroorqanizmlərin antimikrob preparatlara qarşı həssaslığını tədqiq etmişlər. Mikroorqanizmlərin 24\%-i CMNİ zaman1, 19\%-i sidik yolları infeksiyalarında və 10,6\%-i qandan əldə edilmişdir. E.coli əsasən penisillinlərə, III nəsil sefalosporinlərə, siprofloksasinə və gentamisinə davamlı olduğu halda, davamlı Staphylococcus aureus ştammlarının ümumiyyətlə aşkar edilməmişdir. Multirezistent P.aeruginosa ştammlarının hamısı kolistinə həssas olmuşdur. Ümumilikdə, genişlənmiş spektrli beta-laktamaza (GSBL) aktivliyinə malik Enterobacteriaceae fəsiləsindən olan bakteriyaların artması qeyd edilmişdir. Si D. və b. [5] məlumatlarına əsasən koronar arteriyanın şuntlama əməliyyatı edilmiş xəstələrdə CMNI törədicisi olan S.aureus ştammlarında metisillinə rezistentlik 14.6\% hallarda müşahidə edilmişdir Son zamanlar nəinki S.aureus ştammları, eləcə də digər növ (koaqulaza neqativ) stafilokok ştammları arasında metisillinə rezistentlik müşahidə edilir. Qaraciyər transplantasiyasına məruz qalmış pasientlərdə CMNI törədicisi kimi metisillinə rezistent koaqulaza neqativ stafilokokların rolunun artması qeyd edilmişdir [1].

Bizim tədqiqatda CMNI törədicilərinin antibiotiklərə həssaslığını analiz edəkən məlum olmuşdur ki, E.coli və P.aeruginosa ştammlarının antibiotiklərə həssaslığı yuxarıdakı tədqiqatların nəticələrinə müvafiqdir. Belə ki, S.aureus ştammlarında metisillinə rezistentlik $14,3 \%$ rast gəlinərək koronar arteriyanın şuntlama əməliyyatı edilmiş xəstələrlə demək olar ki, eynidir. Lakin bir tədqiqatda [1] CMNI xəstələrindən alınmış metisillin-rezistent S.aureus bütün S.aureus ştammları arasında 72,0\% təşkil etmişdir ki, bu da bizim tədqiqatın nəticələrindən kifayət qədər fərqlənir. Tədqiqat nəticəsində əldə edilmiş E.coli və Klebsiella cinsli bakteriyaların əksər ştammlarında ESBL aktivliyinin aşkar edilməsi də digər tədqiqatların nəticələrini təsdiq edir.

Beləliklə, araşdırma nəticəsində cərrahi müdaxilə nahiyyəsi infeksiyalarının əsas törədicilərinin S.aureus, P.aeruginosa, E.coli, Klebsiella cinsli bakteriyalar, eləcə də Candida cinsli göbələklər olması müəyyənləşdirilmişdir. S.aureus ştammları əsasən penisillinə, ampisilinə, böyük bir qismi isə tetrasiklinə davamlı olmuş, metisillinə rezistentlik az hallarda müşahidə edilmişdir. P.aeruginosa ştammlarının əksəriyyəti seftazidimə, sefepimə, piperasillinə, meropeneme, aztreonama davamlı 
olmuş, ştammların təqribən yarısı induksiya olunan beta-laktamaza (İsBL) aktivliyinə malik olmuşdur. Klebsiella cinsli bakteriya ştammlarının hamısı ampisillino, ampisillin+sulbaktama, amoksisillin+clavunata, sefalosporinlərə, o cümlədən III nəsil sefalosporinlərinə, siprofloksasinə, aztreonama, gentamisinə, trimetoprim- sulfametoksazola, böyük əksəriyyəti isə piperasillin+tazobaktama, ofloksasinə, levofloksasinə, moksifloksasinə, xloramfenikola davamlı olmuşdur. E.coli ştammlarının böyük əksəriyyəti ampisillinə, sefalosporinlərə, o cümlədən III nəsil sefalosporinlərinə, aztreonama, trimetoprimsulfametoksazola davamlı olmuşdur. E.coli və Klebsiella cinsli bakteriya ştammlarının əksəriyyətində ESBL produksiyası müəyyən olunmuşdur.

Maliyyə Mənbəyi: Məqalənin hazırlanmasında heç bir kənar maliyyə mənbəyindən istifadə edilməyib.

Maraqların toqquşması: Qeyd edilməyib.

\section{ӘDӘВIYYAT:}

1.Kawecki D., Pacholczyk M., Lagiewska B. et al. Bacterial and fungal infections in the early post-transplantation period after liver transplantation: etiologic agents and their susceptibility // Transplant Proc. 2014, v.46, №8, p.2777-2781.

2.Li J, Yu L, Yang J, et al. Species distribution of pathogens and prognostic factors for catheterrelated bloodstream infections in intensive care unit // Zhonghua Yi Xue Za Zhi. 2015, 95(9), p.659-662.

3.Najjar P.A., Smink D.S. Prophylactic antibiotics and prevention of surgical site infections // Surg Clin North Am, 2015, v.95, №2, p.269-283.

4.Shahane V, Bhawal S, Lele U. Surgical site infections: A one year prospective study in a tertiary care center // Int J Health Sci. 2012, 6(1), p.79-84

5.Si D, Rajmokan M, Lakhan P. et al. Surgical site infections following coronary artery bypass graft procedures: 10 years of surveillance data
// BMC Infect Dis, 2014, v.10, №14, p.318.

6.Takesue Y., Watanabe A., Hanaki H. et al. Nationwide surveillance of antimicrobial susceptibility patterns of pathogens isolated from surgical site infections (SSI) in Japan // J Infect Chemother, 2012, v.18, №6, p.816-826.

7.Toniolo A., Endimiani A., Luzzaro F. Microbiology of postoperative infections // Surg Infect (Larchmt), 2006, v.7, №2, p.13-16. 